\title{
Recitals for War Funds
}

Author(s): A. H. Mann

Source: The Musical Times, Vol. 58, No. 896 (Oct. 1, 1917), p. 457

Published by: Musical Times Publications Ltd.

Stable URL: http://www.jstor.org/stable/908208

Accessed: 20-06-2016 03:23 UTC

Your use of the JSTOR archive indicates your acceptance of the Terms \& Conditions of Use, available at

http://about.jstor.org/terms

JSTOR is a not-for-profit service that helps scholars, researchers, and students discover, use, and build upon a wide range of content in a trusted digital archive. We use information technology and tools to increase productivity and facilitate new forms of scholarship. For more information about JSTOR, please contact support@jstor.org.

Musical Times Publications Ltd. is collaborating with JSTOR to digitize, preserve and extend access to The Musical Times 
Tropos will be requisitioned, and that from each, one member, the 8 th will be selected for use.

This sequence, which represents a segment of the Harmonic Series, is in reality seen to consist of the keynotes of seven different minor keys borrowed from so many Tropoi. A similar explanation applies to the time element in the pitch of the notes and to the vibrational law when the true harmonics of a clang are considered from the point of view of the physical basis of sound, but there is no opportunity or time to go into the subject here. It is the old question of the hen and the egg.

(9) The point urged by Mr. Fox Strangways is rather damaged by the fact that the 1 th part of an inch which he claims to represent all the difference between the position of a hole bored at $\frac{11}{12}$ from the extremity of the pipe, or at $\frac{1}{1} \frac{\pi}{6}$ (in order to substitute for a certain flattened A, a correctly-tuned AD), applies only to a pipe one inch in length! This one-inch pipe, moreover, would give sounds which the human ear, as at present constituted, would fail fail to apprehend. This is a clear case of Nemesis pursuing Mr. Fox Strangways for pouring contempt upon the Tropos principle and allowing it only a numerical existence and an accidental birth. On a real, not a Lilliputian pipe, measuring 353 metre :

$$
\begin{aligned}
& \frac{353 \times 1 \mathrm{I}}{\mathrm{I} 2}=323.5 \text { position of hole } \mathrm{I} \text { from mouthpiece } \\
& \frac{353 \times 15}{\mathrm{I} 6}=33 \mathrm{I} \quad,, \quad,, \quad, \quad,,
\end{aligned}
$$

The difference $=7 \frac{1}{\frac{1}{2}}$ millimetres, or about I4 times more than Mr. Fox Strangways's computation. Kathleen Schlesinger.

\section{RECITALS FOR WAR FUNDS.}

TO THE EDITOR OF 'THE MUSICAL TIMES.'

SiR,-May I beg for a little of your space to ask my brother musicians for some help. As a result of some sonata recitals that Mr. Alexander Cohen, of Harrogate, has been recently giving - (all honour to him, I say)-he has sent me a cheque for $f 23$ and hopes to send another donation after the end of the approaching season. This money is to be devoted entirely to helping the children, or distressed widow, of some musician who has been killed in the War. The I.S.M. has g'adly undertaken to distribute Mr. Cohen's splendid gift in accordance with his expressed wishes, and would indeed rejoice if any other musician-or body of musicians-would endeavour to do as he has done. We should be most grateful if anybody would kindly send information of any cases which would accord with Mr. Cohen's desires, to Mr. Hugo Chadfield, the general secretary of the I.S.M. I9, Berners Street, London, W.-I ; or to Yours faithfully,

King's Field, (Signed) A. H. MANN,
Hon. Treasurer of

Cambridge. The Incorporated Society of Musicians.

\section{'THE DEPRECIATION AND APPRECIATION OF HANDEL.'}

TO THE EDITOR OF 'THE MUSICAL TIMES.'

Sir,-Would Mr. H. Davey be kind enough to state to what 'anti-Handel outbreak' of mine he refers? I cannot call one to mind.-Yours, \&c.,

I, Minster Court, York,
September I2, I9 7 .

Edward C. Bairstow.

TO THE EDITOR OF 'THE MUSICAL TIMES.'

SIR,-My recollection is that Dr. Bairstow some time since was reported to have contrasted Handel with Bach and not only to have pronounced Bach the greater composer, but to have expressed, with considerable emphasis, his opinion that Handel was far inferior. That Bach was on the whole the greater composer is also my opinion, as I have repeatedly stated; but I do not consider the gap between them nearly so great as Dr. Bairstow was reported to have affirmed, if my recollection is accurate. If I misrepresented his views, apologise unreservedly. - Yours, \&c.,

H. DAVEY.
THE TRANSLATION OF SONGS AND OPERAS INTO ENGLISH.

\author{
BY N. DE V. HART.
}

My subject requires no apology. It is quite true that if every Englishman knew French, German, Italian, Russian, Spanish, and the Scandinavian languages, there would be no necessity for the writing of this article ; but as few Englishmen know, at the most, more than one other language beside their own, it seems clear that it is, and for a considerable time will be, needful to have songs and operas translated from foreign languages into English.

Assuming, then, that we must have translations, the question arises: Are our present methods of translating satisfactory? Ask the singers : they will tell you that for the most part translations are unsingable. Ask the poets : they will tell you that they cannot go to a concert or an opera without feeling that their muse has been insulted. Ask musicians : they will tell you that translators have no respect for musical phrasing, accent, or rhythm. Ask audiences and critics : they will tell you that most translations sound either bald or incongruous, and almost invariably render the task of the singer so difficult that his discomfort is inevitably communicated to the listener.

The reason for this state of things is not far to seek. The average translation is bad from many points of view, but all its faults arise from one single, fundamental error: the translator has a false conception of the aim of a transiation. The aim of the average translation is to reproduce in English the effect of the poem as it is when written on paper and read : the translation appeals to the eve of a reader. The true aim should be to reproduce the effect of the poem as it is sung : it should appeal to the ear of the person who listens to the translation set to music. This is the root of the matter, stated broadly; its full significance will become clear as we proceed.

An ideal and prrfect translation would be one that obeyed in complete detail the following rules, which I would classify thus :

Firstly, there is the poetic, or spiritual, requirement :

Rule I. - The translation must reproduce, in suitable language, the spirit and meaning of the original poem. Secondly, there are the musical requirements :

Rule 2.-The translation must preserve the rhythm of the music and the unity of the musical phrase.

Rule 3.- The important note or notes which bear the important word or words in the original, must bear also the important word or words in the translation. The climax of the words and the climax of the music must synchronise.

Rule 4.-Accented syllables must fall on accented notes.

Rule 5.-Where in the original one syllable is spread over two or more notes, the same thing must happen in the translation.

Thirdly, there are the requirements of the singer :

Rule 6.-The vowels of the original poem must be reproduced by similar vowels in the translation.

Rule 7. - The consonants of the original poem must be reproduced by similar consonants in the translation.

Rule 8.-Suitable moments for breathing must be provided.

Rule 9.-The distribution of syllables must be such as to permit of flowing, easy pronunciation.

Rule 10.- The construction of the sentences must be simple, and free from complicated parentheses and inversions.

Finally, there are the literary requirements :

Rule I I. - The translation must reproduce the metre of the original poem.

Rule 12. - The translation must reproduce the rhyming scheme of the original poem.

Rule I3. - The translation must reproduce the rhythm of the original poem.

Rule I4. - The translation must reproduce all the special poetic devices of the original poem, such as alliteration, assonance, grouping of vowels and consonants.

Now it is obvious that no translation can satisfy all these requirements at once. In this lies the peculiar difficulty of translating : at every point a large number of these requirements have to be set aside, and it rests with the tact, 